\title{
Seasonal variation in hornbill abundance in a West African national park detected using analysis of acoustic recordings
}

\author{
HUGO J. RAINEY and KLAUS ZUBERBÜHLER
}

\begin{abstract}
Summary
Distance sampling, line transects and radio-tracking have been used previously to estimate population abundances and movements of hornbills. We used a large dataset of audio recordings made over 1o years to estimate seasonal variation in abundance of three species: Black-casqued Hornbill Ceratogymna atrata, Yellow-casqued Hornbill C. elata and Brown-cheeked Hornbill Bycanistes cylindricus, in Taï National Park, Côte d'Ivoire. The latter two species are Near Threatened. Recordings of hornbill wing-beats were used to control for potential seasonal variation in call production. Yellow- and Black-casqued Hornbill calls were 1o times as abundant from July to February as they were from March to June. Brown-cheeked Hornbills showed a similar trend, but less pronounced. From these data we concluded that large numbers of Yellowand Black-casqued Hornbills had left the Taï National Park during this period. The significance of these findings is discussed in relation to the fragmentation and regeneration of the Upper Guinea forests and the relatively small size of the remaining forest habitat in the region.
\end{abstract}

\section{Résumé}

Les taux d'abondance et de mouvement des populations de calaos étaient auparavant estimés par un échantillonnage et des analyses sur le logiciel Distance, des transects linéaires et des repérages télémétriques. Nous avons eu recours à un grand ensemble d'enregistrements audio effectués sur plus de 1o ans afin d'estimer la variation saisonnière de l'abondance de trois espèces rencontrées dans le Parc National de Taï, en Côte d'Ivoire : le Grand Calao à Casque Noir Ceratogymna atrata, le Grand Calao à Casque Jaune Ceratogymna elata et le Calao à Joues Brunes Bycanistes cylindricus. Ces deux dernières espèces sont aujourd'hui considérées comme presque menacées. Nous avons procédé à des enregistrements de battements d'ailes pour tester une potentielle variation saisonnière de la production des cris. Les cris des Grands Calaos à Casque Jaune et à Casque Noir étaient dix fois plus abondants entre juillet et février qu'entre mars et juin. En revanche, les Calaos à Joues Brunes n'ont présenté qu'une petite variation du taux d'abondance entre ces deux périodes. D'après ces données, nous avons conclu qu'un grand nombre de Calaos à Casque Jaune et à Casque Noir quittent le Parc National de Taï entre mars et juin. La signification de ces découvertes est discutée en tenant compte de la fragmentation et de la régénération des forêts de Haute Guinée ainsi que de la dimension relativement petite de $l^{\prime}$ habitat forestier subsistant dans cette région.

\section{Introduction}

A number of Asian and African hornbill species are known to make local and long-distance movements in response to changes in fruit availability (e.g. Kalina 1988, Modse 1988, Poonswad 
and Tsuji 1994, Kinnaird et al. 1996, Anggraini et al. 2000, Datta and Rawat 2003). In Cameroon, hornbills vary in abundance with fruit resources and they make long-distance movements linked to seasonal variation in fruit availability (Whitney and Smith 1998, Holbrook and Smith 2000, Holbrook et al. 2002). Similarly, observations during a study on hornbill behaviour in Taï National Park, Côte d'Ivoire, indicated that both Yellow-casqued and Blackcasqued Hornbills were encountered less often in some months than others (Rainey et al. 2004a, b; see also Thiollay 1985, Gartshore et al. 1995). For example, H. J. R. encountered three or four flocks of Yellow-casqued Hornbills per day from November to December 2001 compared with only one flock every 4-5 days from March to May 2002, although there were no obvious differences in flock size. Most flocks consisted of four or fewer individuals.

Hornbill movements and variation in abundance are usually monitored with radio-tracking, point counts, line transects and distance sampling (Holbrook and Smith 2000, Holbrook et al. 2002, Gartshore et al. 1995, Kinnaird et al. 1996, Whitney and Smith 1998, Marsden 1999). Our initial plan was to estimate the abundance of hornbills in the Tai forest using distance sampling (Buckland et al. 2001), but the outbreak of political unrest in Côte d'Ivoire in September 2002 thwarted this study. However, K. Z. had a large dataset of audio recordings made in the same study area in the Taï Forest between 1991 and 2002 during fieldwork on primate vocal behaviour (e.g. Zuberbühler et al. 1997, Zuberbühler 2000, 2003, Eckardt and Zuberbühler 2004). This presented us with a unique opportunity to investigate hornbill abundance by comparing rates of hornbill acoustic behaviour throughout the years. In this study, we use calling frequency determined from acoustic recordings to investigate seasonal changes in hornbill abundance in the Taii National Park. We consider the efficacy of using the method in other situations, and discuss the implications of the results in relation to hornbill conservation.

Eight species of hornbill have been described for the Taï National Park (Gartshore et al. 1995). In addition, Black-and-white-casqued Hornbill (Bycanistes subcylindricus) has recently been found in the Cavally Forest Reserve $\left(6^{\circ} 11^{\prime}\right.$ N, $7^{\circ} 47^{\prime}$ W) north-west of Taï National Park (Demey and Rainey 2006), suggesting that this species may also be present in the semi-deciduous forest in the north of the Park. Here, we focus on the three largest hornbill species: Black-casqued, Yellow-casqued and Brown-cheeked Hornbills; the latter two are of global conservation concern and classified as Near Threatened (BirdLife International 2000). These three species are also the most vocal and frequently observed in closed forest (Gartshore et al. 1995), suggesting they were most likely to provide sufficient data for abundance estimates.

Some bird species vocalize only during certain times of the year, especially those that live in highly seasonal habitats (e.g. Keith et al. 1992, Catchpole and Slater 1995). Therefore, it was important to be certain that hornbill densities varied genuinely in the study area, rather than the birds changing their call rates. We therefore analysed a second acoustic measure, the occurrence of wing-beat noise produced by flying individuals. Hornbills lack under-wing coverts and thus have noisy wing-beats that can be heard from considerable distances (Kemp 1995, Kinnaird et al. 1996, Rainey et al. 2004a, b). The birds fly year-round, although females seal themselves into their nest-hole during incubation of the eggs and young. However, in the Upper Guinea region Yellow-casqued Hornbill does not appear to have a distinct breeding season (Grimes 1987, Gartshore et al. 1995, Kemp 1995, H. J. R. pers. obs.). Similarly, Brown-cheeked Hornbill has been found in breeding condition in January and August (Kemp 1995) and, in Ghana, a nestling Black-casqued Hornbill was found in November (Grimes 1987). It is therefore unlikely that changes in rates of wing-beat noise are caused by less locomotor activity due to a breeding season.

\section{Methods}

\section{Data collection}

K. Z. made audio recordings in Taï National Park around the Centre de Recherche en Ecologie (CRE) $\left(5^{\circ} 50^{\prime} \mathrm{N}, 7^{\circ} 21^{\prime} \mathrm{W}\right)$ covering an area of about $100 \mathrm{~km}^{2}$. This work was carried out from 
Table 1. Total number of recordings subjected to analyses between 1991 and 2002.

\begin{tabular}{llr}
\hline Month & Year & $n$ \\
\hline January & 1997,1999 & 52 \\
February & 1997, 1999-2000 & 101 \\
March & 1997,2000 & 33 \\
April & 1997 & 50 \\
May & 1997 & 71 \\
June & $1994-1997,2002$ & 70 \\
July & $1994-1996$ & 54 \\
August & 1994,1996 & 43 \\
September & 1991,1996 & 34 \\
October & 1996 & 70 \\
November & 1996,2001 & 39 \\
December & $1998,2000-2001$ & 50 \\
Total & 10 years & 667 \\
\hline
\end{tabular}

$n$, the total number of 5 minute blocks of continuous recordings conducted between 07:00 and 18:00 hours.

March to June 1991 and June 1994 to June 2002 inclusive, although not in every month of every year (Table I).

All recordings were made as part of behavioural studies on various primates, such as Cercopithecus diana, C. campbelli, C. nictitans, Cercocebus atys and Colobus polykomos. Hence all recordings were made in the presence of primates, irrespective of the presence or absence of hornbills. The recordings were of high quality, tape-recorded with a Sony Professional Walkman and Sennheiser directional microphones, allowing analyses of the vocal behaviour of numerous non-primate species in addition to those of the focal primate groups.

The observer (K. Z.) searched for monkey groups at random along transects in the study area. Once a monkey group was located, usually a group of Diana Monkeys associated with one or several other monkey species, the group was observed with the attempt to conduct a playback experiment to address a particular problem in primate cognition (Zuberbühler 2003). The observer stayed with a monkey group and proceeded to conduct an experiment only if (I) no alarm calls had been emitted for at least 30 minutes, (2) it could safely be assumed that no monkey had detected the observer or part of the equipment and (3) no natural predation event had occurred for at least 30 minutes. Recordings of the subject groups' vocal behaviour began 5 minutes before the start of the playback trial and lasted for 15 minutes. In this study, we only inspected the 5 minutes pre-playback recordings that were routinely obtained as part of these playback experiments. From these recordings we then scored whether or not we could hear hornbill vocalizations or wing-beats of the different species. We deliberately did not analyse any recordings during or after playback stimulus was broadcasted because our previous work had shown that hornbill response rate varied significantly depending on the types of acoustic stimulus (Rainey et al. 2004a, b). Hence, the 5 minute pre-playback recordings provided us with unbiased information.

Although hornbills forage on some of the same tree species as primates, the extent of dietary overlap is low (Poulsen et al. 2002). Thus it is unlikely that any seasonal variation in associations of hornbills and primates will have had a strong influence on our results. Additionally, as hornbills have very loud calls, which occasionally can be heard from over $\mathrm{I}$ km away (Kemp 1995, Rainey et al. 2004a, b), all hornbill calls made within a few hundred metres of the microphone were likely to be recorded even if they were not associated with primates. Each recording lasted $5 \mathrm{~min}$ and was separated from other recordings spatially by at least $500 \mathrm{~m}$, or temporally by 1 year, thus ensuring independence of each recording. A total of 667 recordings $(3,335 \mathrm{~min})$ were analysed, varying from 33 to 101 recordings per month (Table 1 ). All available recordings were used. 


\section{Data analyses}

In the Taï Forest, plant production is generally related to rainfall. Monthly rainfall follows an annual cycle with a distinct dry season, usually from December to January, and one main rainy season that usually peaks in October. Our overall hypothesis was that seasonal differences in hornbill abundance were related to differences in food availability and rainfall. As the recordings were made in every month of the year, we could assess the variation in abundance of all three hornbill species from the proportion of recordings on which the call of each species was found in a particular month.

To control for potential seasonal variation in call production by hornbills, we compared the proportion of recordings in each calendar month, in which we noted wing-beats, against the proportion of recordings in each month that hornbills called. Since we operated with proportions we converted these data to their arcsines before calculation of the regressions. These analyses were conducted for both Black- and Yellow-casqued Hornbills combined and for each species separately. In the wing-beat data, we did not distinguish between those produced by Yellowcasqued and Black-casqued Hornbills. The wing-beats of large male Yellow-casqued Hornbills can be distinguished from those of Black-casqued Hornbills, but species identification is much more unreliable for the other age-sex classes. It was possible to separate wing-beats of Browncheeked Hornbills, which are smaller (0.9-1.4 kg, wing length 276-330 mm) than Black-casqued (0.9-1.6 kg, wing length 330-440 mm) and Yellow-casqued Hornbills (1.5-2.1 kg, wing length $344-415 \mathrm{~mm}$ ) (ranges are maxima; Kemp 1995). Brown-cheeked Hornbill wing-beats are faster and less deep and can be distinguished from those of the larger two species. Although noisy, they were more difficult to score from the audiotapes and were therefore excluded from our analyses. Recordings of calls were displayed as spectrograms with Avisoft-SASLab Pro 3.9. Taxonomy and nomenclature follow Borrow and Demey (2002).

\section{Results}

\section{Variation in wing-beat abundance}

The proportion of recordings that contained sounds of wing-beats of Black- and Yellow-casqued Hornbills was strongly related to the proportion of recordings that contained their calls (Fig. I).

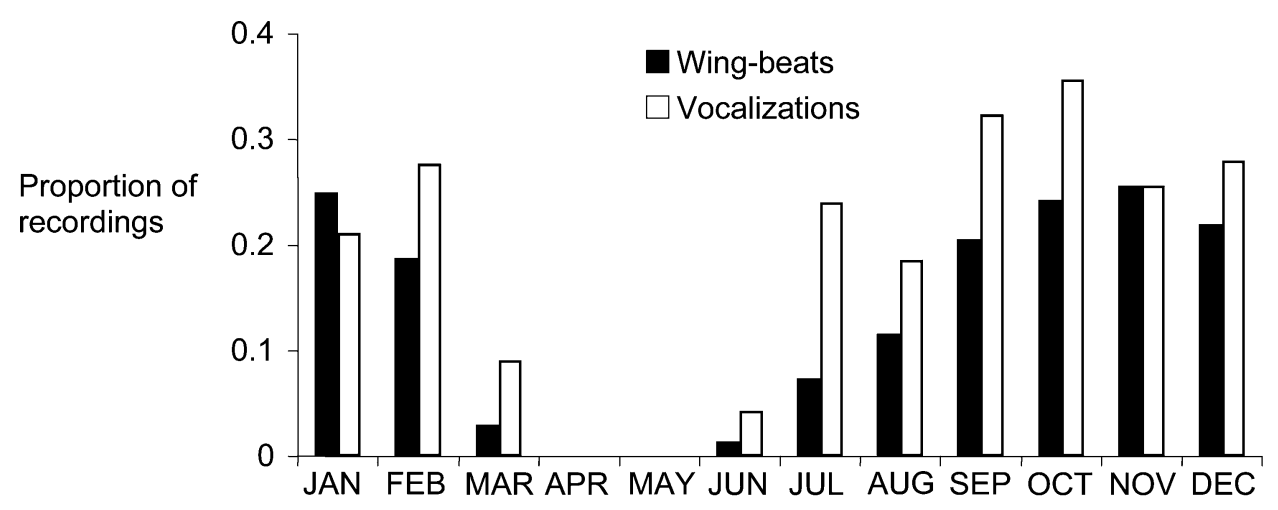

Month

Figure 1. Proportion of recordings per month on which wing-beats (black bars) and calls (white bars) of Black-casqued and/or Yellow-casqued Hornbills were recorded. 
This was the case if the calls of both species were analysed together $\left(r^{2}(\operatorname{adj})=0.74 ; \mathrm{F}_{1,10}=33.0\right.$; $P<$ 0.001), or separately (Black-casqued Hornbills: $r^{2}\left(\right.$ adj) $=0.72 ; \mathrm{F}_{1,10}=28.9 ; P<0.001$; Yellow-casqued Hornbills: $r^{2}$ (adj) $=0.43 ; \mathrm{F}_{1, \text { 10 }}=9.43 ; P=0.012$ ). As expected, there was no relation between the wing-beats of the larger two hornbill species and the calls of Browncheeked Hornbills $\left(r^{2}\right.$ (adj) $\left.=0.040 ; F_{1,10}=1.45 ; P=0.256\right)$.

The occurrence of wing-beats peaked from September to January and was lowest from March to June. The difference between the proportions of recordings on which wing-beats were heard differed significantly between the period July to February (19.4\% of recordings) and March to June (o.8\% of recordings; Fisher's exact test: $n=224,443, P<0.001$; Fig. 1 ).

\section{Variation in vocalization abundance}

There was a significant difference between the number of recordings on which Black- and/or Yellow-casqued Hornbill calls were heard from July to February (27.1\% of recordings) compared with the period March to June ( $2.7 \%$ of recordings; Fisher's exact test: $n=224,443, P<0.001$ ). The same pattern emerged if the two species were analysed separately (Black-casqued Hornbills: July to February, $18.7 \%$ of recordings; March to June, 1.8\% of recordings; Fisher's exact test: $n$ $=224,443, P<0.001$, Fig. 2; Yellow-casqued Hornbills: July to February, 10.8\% of recordings; March to June, $0.8 \%$ of recordings; Fisher's exact test: $n=224,443, P<0.001$, Fig. 3 ). The calls of Brown-cheeked Hornbills showed no significant variation in abundance between the two seasons (July to February, 4.1\% of recordings; March to June, 1.3\% of recordings; Fisher's exact test: $n=224,443 ; P=0.062$, Fig. 4 ).

There appears to be a causal relationship between the presence of these three species of hornbill and annual patterns of rainfall. All three species leave the Taï National Park for about 3 months, roughly $1-2$ months following the start of the main dry season from December to January, most likely due to depletion of key food resources.

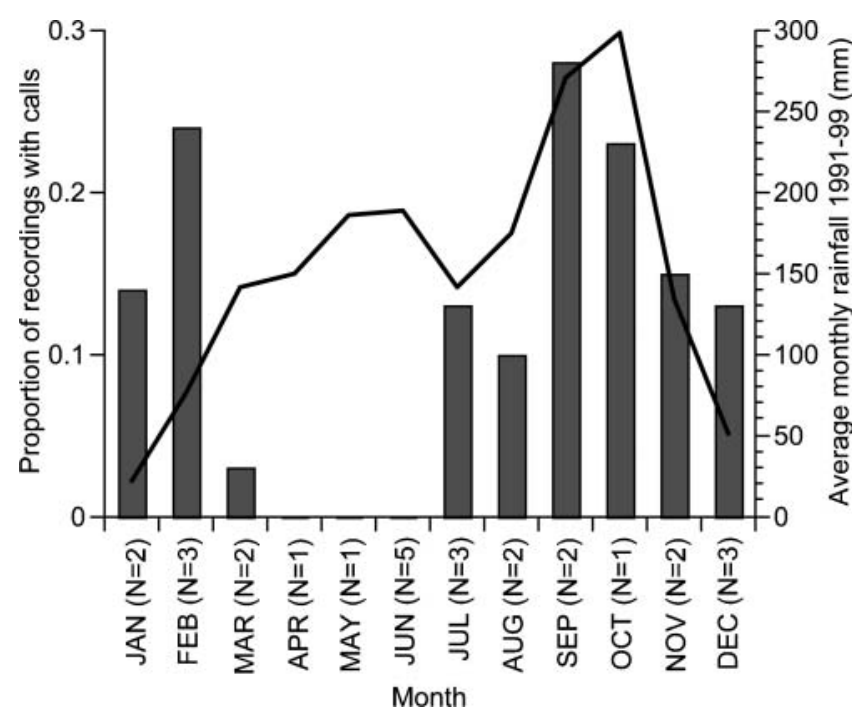

Figure 2. Proportion of recordings per month on which calls of Black-casqued Hornbills were recorded in relation to average monthly rainfall in the same area $(n=$ number of years for which recordings were available; see Table 1 for recording sample size). 


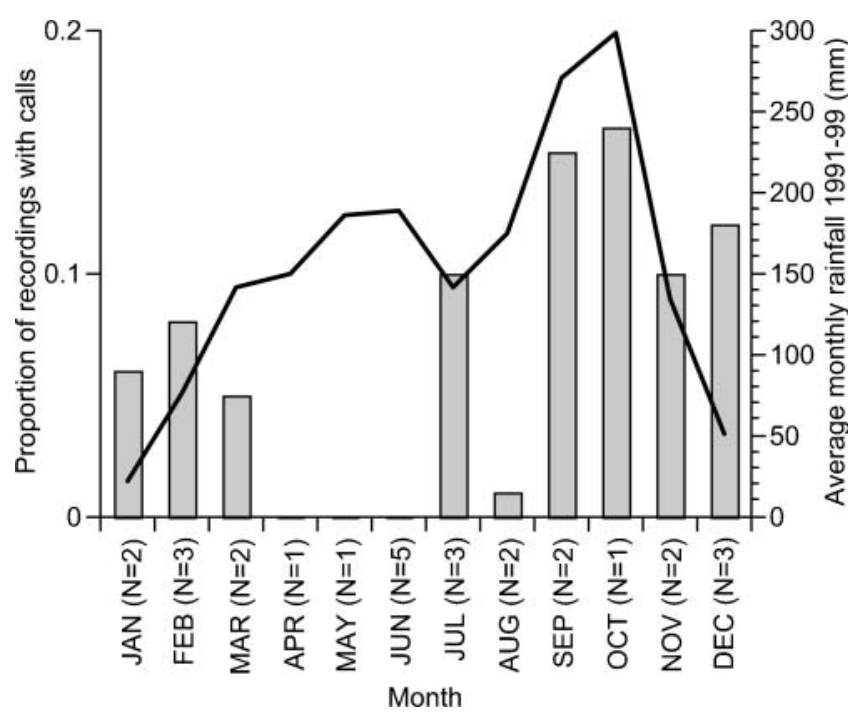

Figure 3. Proportion of recordings per month on which calls of Yellow-casqued Hornbills were recorded in relation to average monthly rainfall in the same area $(n=$ number of years for which recordings were available; see Table 1 for recording sample size).

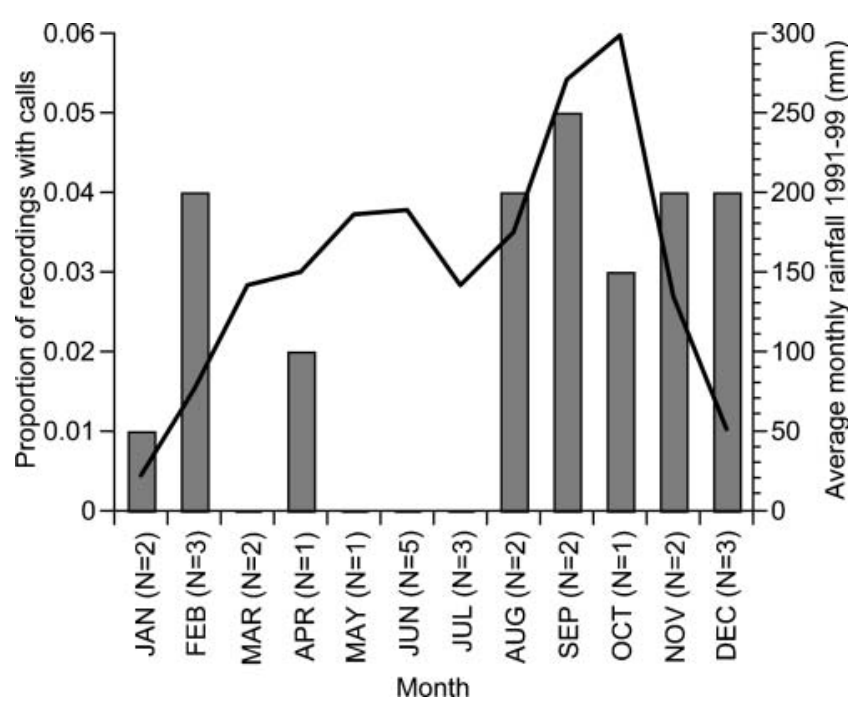

Figure 4. Proportion of recordings per month on which calls of Brown-cheeked Hornbills were recorded in relation to average monthly rainfall in the same area $(n=$ number of years for which recordings were available; see Table 1 for recording sample size).

\section{Discussion}

We used audio recordings systematically collected during studies of primate behaviour to detect seasonal variation in abundance of forest hornbills in 1o different years. Recordings were of high quality and have been used in other studies on behaviour (e.g. Zuberbühler et al.. 1997, 
Zuberbühler 2000, 2003, Rainey et al. 2004a). We found that incredibly rich information on the vocal behaviour of forest bird species, including hornbills, was accessible in these recordings. Audio recordings made in studies elsewhere could contain similar useful data for population status evaluations. Such data, if collected over long time periods, could provide invaluable longitudinal data and potentially detect population trends in species, which are often poorly known.

We noted numbers of recordings on which Yellow-casqued, Black-casqued and Brown-cheeked Hornbills called or their wing-beats were heard for each month of the year. We were able to detect whether hornbills were present during a particular recording and could thus estimate seasonal variation in abundance from all recordings. Our data suggest that either (a) the two species dramatically alter their locomotor and vocal activity from March to June or (b) most of them leave the Taï National Park during this period. The prevalence of hornbill wing-beats was closely related to the prevalence of the calls of Black- and Yellow-casqued Hornbills, analysed together or separately, suggesting that the differences in vocalization rates were not due to vocal inactivity. More likely, both species showed significant seasonal variation in abundance. They were almost to times more common from July to February compared with March to June. Brown-cheeked Hornbills showed the same basic patterns, but low statistical power may have prevented us from detecting significant differences. This species makes fewer and quieter vocalizations than the other two, and calls will thus be detected over smaller areas than the ones of the two Ceratogymna species, possibly leading to an underestimation of its relative abundance.

Are Black- and Yellow-casqued Hornbills engaging in nomadism or migration? Nomadism would imply that the birds are tracking available resources on an ad hoc basis with no seasonal bias. Our study included data collected from to different years, an unusually long sampling period. If the birds were nomadic it would be unlikely that we would have detected a seasonal bias in their variation in abundance. Moreover, these birds do not appear to have fixed breeding seasons and breeding can occur during both dry and rainy seasons (Grimes 1987, Gartshore et al. 1995, Kemp 1995, H. J. R. pers. obs.). They do not defend territories, are highly mobile, and are able to move between ephemeral fruiting sources (e.g. Leighton 1986, Poonswad and Tsuji 1994, Kinnaird et al. 1996, Holbrook and Smith 2000, Holbrook et al. 2002). A much more plausible explanation is that the majority of these birds leave the park during parts of the year, a rare example of bird migration in a tropical rainforest. There are only very few observations of forest stenotopic species migrating in the West African forests (Elgood et al. 1973, Thiollay 1985, Grimes 1987) and Black- and Yellow-casqued Hornbills may be amongst the few species that do so. Our data show that the birds leave the Tai forest for a total of 3-4 months, following the main dry season. Food availability may be poor during this time period, influencing bird movements, but this is a hypothesis requiring further study, as hornbill diet is virtually unknown in Upper Guinea.

The variation in abundance of Black- and Yellow-casqued Hornbills and their probable movement to areas outside Taï Forest has important implications, especially for their conservation. Firstly, it is likely that they require a larger area of forest than is available to them with the Taï National Park alone. They probably do not migrate southwards as they were uncommon in Haute Dodo Forest Reserve ( $\left.4^{\circ} 54^{\prime} \mathrm{N}, 7^{\circ} 19^{\prime} \mathrm{W}\right)$, south of Taï National Park, during a survey conducted in March 2002 (Demey and Rainey 2006). It is possible that they migrate into the northern semi-deciduous forest, for example Mont Péko $\left(6^{\circ} 58^{\prime} \mathrm{N}, 7^{\circ} 12^{\prime} \mathrm{W}\right)$ and Mont Sangbé NPs $\left(8^{\circ} \mathrm{Oo}\right.$ ' N, $\left.7^{\circ} 12^{\prime} \mathrm{W}\right)$, which have a different rainfall regime to the southern moist forest (Thiollay 1985). Although there are hornbills present year-round in these parks, they do appear to vary in numbers throughout the year (R. Demey verbally, H. J. R. pers. obs.). The consequence of this is that these species may require very large tracts of forest to maintain their populations at current levels, as has been observed in Asia (Datta and Rawat 2003). It has previously been suggested that, in the process of estimating minimum protected area size, the critical habitats used throughout the annual cycle of a species should be identified and protected (Powell and Bjork 1995). This is a problem that has not yet been addressed for the two nearthreatened hornbills in West Africa. 
Secondly, the massive reduction in forest area over the last 25 years in Upper Guinea, and particularly in Côte d'Ivoire, has resulted in widespread fragmentation of the remaining forests, leading to habitat loss for the hornbill population (Sayer et al. 1992). In the process, local populations may have become isolated, reduced in numbers, or gone locally extinct. For example, Black-casqued Hornbill has not been observed in Marahoué National Park ( $7^{\circ} \mathrm{O} 8^{\prime} \mathrm{N}, 5^{\circ} 56^{\prime} \mathrm{W}$ ) for over 20 years (Thiollay 1985, H. J. R. pers. obs.), and this may be related to the Park's recent isolation from other areas of forest. Hornbills are known to be excellent seed dispersers and they are amongst the few remaining species that can disperse seeds to isolated forest fragments (e.g. Jensch and Ellenberg 1999, Chapman et al. 2003). However, it is possible that very large expanses of non-forest habitat may exclude hornbills from the more isolated fragments. Smaller fragments may also not support sufficient fruiting trees to enable populations of some species to survive (Raman and Mudappa 2003). This isolation may have important consequences for forest regeneration from dispersed seeds.

Thirdly, hunting of all large wildlife species for meat is the greatest threat to their survival in most of forested Central and West Africa (Barnes 2002 Milner-Gulland and Bennett 2003). Large hornbills are hunted in the Upper Guinea region, particularly where other large wildlife species have been eliminated (H. J. R. pers. obs.). As hornbills must fly across areas of non-forest habitat to reach forest fragments, it is possible that they may suffer an increased risk of mortality from hunting than if they were sedentary in closed forest.

\section{Acknowledgements}

We are grateful to Peter Slater, Will Cresswell and Ross McGregor for comments on a draft of this manuscript. Mandy Korstjens and Ron Demey provided additional data. We thank Marion Laporte for French translations. H. J. R. thanks Jennifer McCullough for providing funding opportunities during this study and Peter Slater, Ailsa Ritchie and colleagues at the University of St Andrews for support.

\section{References}

Anggraini, K., Kinnaird, M. and O'Brien, T. (2000) The effects of fruit availability and habitat disturbance on an assemblage of Sumatran hornbills. Bird Conserv. Int. 10: 189-202.

Barnes, R. F. W. (2002) The bushmeat boom and bust in West and Central Africa. Oryx 36: $236-242$.

BirdLife International (2000) Threatened birds of the world. Barcelona and Cambridge, U.K.: Lynx Edicions and BirdLife International.

Borrow, N. and Demey, R. (2002) Birds of western Africa. London: Christopher Helm.

Buckland, S. T., Anderson, D. R., Burnham, K. P. and Laake, J. L. (2001) Introduction to distance sampling: Estimating abundance of biological populations. Oxford: Oxford University Press.

Catchpole, C. K. and Slater, P. J. B. (1995) Bird song: Biological themes and variations. Cambridge: Cambridge University Press.

Chapman, C. A., Chapman, L. J., Vulinec, K., Zanne, A. and Lawes, M. J. (2003) Fragmentation and alteration of seed dispersal processes: an initial evaluation of dung beetles, seed fate, and seedling diversity. Biotropica 35: 382-393.

Datta, A. and Rawat, G. S. (2003) Foraging patterns of sympatric hornbills during the nonbreeding season in Arunachal Pradesh, northeast India. Biotropica 35: 208-218.

Demey, R. and Rainey, H. J. (2006) A rapid survey of the birds of Haute Dodo and Cavally Forest Reserves. In L. E. Alonso, F. Lauginie and G. Rondeau, eds. A rapid biological assessment of two classified forests in south-western Cote d'Ivoire. RAP Bulletin of Biological Assessment 34. Washington, D.C.: Conservation International. 
Eckardt, W. and Zuberbühler, K. (2004) Cooperation and competition in two forest monkeys. Behav. Ecol. 15: 400-411.

Elgood, J. H., Fry, C. H. and Dowsett, R. J. (1973) African Migrants in Nigeria. Ibis 115: 1-45.

Gartshore, M. E., Taylor, P. D. and Francis, I. S. (1995) Forest birds in Cote d'Ivoire. Cambridge: BirdLife International.

Grimes, L. G. (1987) The birds of Ghana. London: British Ornithologists Union.

Holbrook, K. M. and Smith, T. B. (2000) Seed dispersal and movement patterns in two species of Ceratogymna hornbills in a West African tropical lowland forest. Oecologia 125: 249-257.

Holbrook, K. M., Smith, T. B. and Hardesty, B. D. (2002) Implications of long-distance movements of frugivorous rain forest hornbills. Ecography 25: 745-749.

Jensch, D. and Ellenberg, H. (1999) The hornbill (Tockus semifasciatus) as a seed-disperser and ecological indicator, and forest rehabilitation in eastern Ivory Coast. Revue d' Ecologie - La Terre et la Vie 54: 333-350.

Kalina, J. (1988) Ecology and behaviour of the black-and-white casqued hornbill (Bycanistes subcylindricus subquadratus) in Kibale Forest, Uganda. Michigan State University.

Keith, S., Urban, E. K. and Fry, C. H., eds. (1992) The birds of Africa. Volume IV. London: Academic Press.

Kemp, A. (1995) The hornbills. Oxford: Oxford University Press.

Kinnaird, M. F., O'Brien, T. G. and Suryadi, S. (1996) Population fluctuation in Sulawesi red-knobbed hornbills: Tracking figs in space and time. Auk 113: 431-440.

Leighton, M. (1986) Hornbill social dispersion: variations on a monogamous theme. Pp. 108-130 in D. I. Rubinstein and R. W. Wrangham, eds. Ecological aspects of social evolution: Birds and mammals. Princeton: Princeton University Press.

Marsden, S. J. (1999) Estimation of parrot and hornbill densities using a point count distance sampling method. Ibis 141: 377-390.

Milner-Gulland, E. J. and Bennett, E. L. (2003) Wild meat: the bigger picture. Trends Ecol. Evol. 18: 351-357.

Modse, S. V. (1988) Some aspects of ecology and behaviour of hornbills with special reference to Antracoceros coronatus (Boddaert) from North Kanara District of Western Ghats. Dharwad: Karnatak.

Poonswad, P. and Tsuji, A. (1994) Ranges of males of the Great Hornbill Buceros bicornis, Brown Hornbill Ptilolaemus tickelli and Wreathed Hornbill Rhyticeros undulatus in Khao-Yai-National-Park, Thailand. Ibis 136: 79-86.

Poulsen, J. R., Clark, C. J., Connor, E. F. and Smith, T. B. (2002) Differential resource use by primates and hornbills: Implications for seed dispersal. Ecology 83: 228-240.

Powell, G. V. N. and Bjork, R. (1995) Implications of intratropical migration on reserve design: a case-study using Pharomachrus mocinno. Conserv. Biol. 9: 354-362.

Rainey, H. J., Zuberbuhler, K. and Slater, P. J. B. (2004a) Hornbills can distinguish between primate alarm calls. Proc. $R$. Soc. Lond. B 271: 755-759.

Rainey, H. J., Zuberbuhler, K. and Slater, P. J. B. $(2004 \mathrm{~b})$ The responses of black-casqued hornbills to predator vocalisations and primate alarm calls. Behaviour 141: 1263-1277.

Raman, T. R. S. and Mudappa, D. (2003) Correlates of hornbill distribution and abundance in rainforest fragments in the southern Western Ghats, India. Bird Conserv. Int. 13: 199-212.

Sayer, J. A., Harcourt, C. S. and Collins, N. M. (1992) The conservation atlas of tropical forests: Africa. Basingstoke: Macmillan.

Thiollay, J. M. (1985) The birds of Ivory Coast. Malimbus 7: 1-59.

Whitney, K. D. and Smith, T. (1998) Habitat use and resource tracking by African Ceratogymna hornbills: implications for seed dispersal and forest conservation. Anim. Conserv. 1: 107-117.

Zuberbühler, K. (2000) Interspecific semantic communication in two forest monkeys. Proc. R. Soc. Lond. B 267: 713-718.

Zuberbühler, K. (2003) Referential signalling in non-human primates: cognitive precursors and limitations for the evolution of language. Adv. Stud. Behav. 33: 265-307.

Zuberbühler, K., Noë, R. and Seyfarth, R. M. (1997) Diana monkey long-distance calls: messages for conspecifics and predators. Anim. Behav. 53: 589-604. 
HUGO J. RAINEY

School of Biology, Bute Medical Buildings, University of St Andrews, St Andrews, KY16 9TS, U.K.

Current address: Lac Tele Community Reserve Project, WCS-Congo, BP 14537, Brazzaville, Congo.

\section{KLAUS ZUBERBÜHLER*}

School of Psychology, University of St Andrews, St Andrews, KY16 9JP, U.K.

${ }^{*}$ Corresponding author.e-mail:kz3@st-andrews.ac.uk

Received 4 October 2004; revision accepted 29 September 2006 